\title{
Segundas estórias: uma outra leitura de "Famigerado"
}

Luís Bueno

Universidade Federal do Paraná

\begin{abstract}
É possível, porém, que não conseguisse enganá-lo convenientemente e que ele fizesse comigo o jogo que eu fazia com ele. Sendo assim, acho que representou bem, pois cheguei a capacitar-me de que ele não desconfiava de mim. Ou então quem representou bem fui eu, se o convenci de que tinha ido ali politicar. Se ele pensou isso, era doido. Provavelmente não pensou. Talvez tenha pensado depois de iludir-se e julgar que estava sendo sincero. Foi o que me sucedeu.

(Graciliano Ramos, S. Bernardo)
\end{abstract}

Resumo: Partindo da hipótese de que os contos de Primeiras estórias contenham as "Segundas estórias" jamais publicadas, este artigo propóe um método de leitura para o livro como um todo exemplificado com a análise de um deles, "Famigerado".

Palavras-chave: Guimarães Rosa, Ficção brasileira, Modernização. 


\section{Um enigma, não um mistério}

Em seu célebre texto sobre Tutaméia, Paulo Rónai conta ter feito a Guimarães Rosa uma pergunta que todos os leitores gostariam de ter feito:

- Por que Terceiras Estórias - perguntei-lhe - se não houve as segundas?

- Uns dizem: porque escritas depois de um grupo de outras não incluídas em Primeiras Estórias. Outros dizem: porque o autor, supersticioso, quis criar para si a obrigação e a possibilidade de publicar mais um volume de contos, que seriam então as Segundas Estórias.

- E que diz o autor?

- O autor não diz nada - respondeu Guimarães Rosa com uma risada de menino grande, feliz por ter atraído o colega a uma cilada. ${ }^{1}$

A resposta é que não é muito satisfatória, conduzindo todos os perguntadores àquilo mesmo: uma cilada. Mas a falta de uma resposta precisa não faz com que a pergunta em si seja tola ou estéril. Na verdade, estamos diante de mais um dos enigmas que povoam a obra de Guimarães Rosa. Ora, como toda pergunta anseia, ainda que muitas vezes em vão, por uma resposta, todo enigma requer uma decifração. Ficar extasiado diante do enigma pode ser sinal de outra coisa, sobre a qual José Antonio Pasta Júnior, numa abordagem sobre o Grande sertão: veredas, observa:

Tudo se passa como se, por sua constituição mesma e pelo pacto que firma com seu leitor, esse livro transcendesse a categoria estético-literária do enigma, que no entanto também é a sua, para tender àquela, mágicoreligiosa, do mistério. Como se sabe, enigmas pedem decifração; mistérios admitem unicamente culto e celebração. ${ }^{2}$

Não só Grande sertão: veredas, mas toda a obra de Guimarães Rosa tem sido objeto de culto e seus enigmas tendem a ser transformados em mistérios, sendo vistas quase como sacrilégio - ou pelo menos como acabada tolice - as tentativas de decifração, como se, alçados à categoria dos mistérios, esses enigmas só fossem abordáveis por meio de impossíveis revelações, com o grau absoluto de verdade que caracteriza toda revelação.

1. RÓNAI. Especulações sobre Tutaméia, p. 14.

2. PASTA JÚNIOR. O romance de Rosa: temas do Grande sertão e do Brasil, p. 61-62. 
Ainda assim, correndo o risco da tolice, a ideia aqui é insistir um pouco em tirar partido do enigma: propor uma possível decifração e, com isso, estabelecer um método de leitura de todo o volume Primeiras estórias, já que a solução proposta para o enigma está naquele livro. Em seguida, como não é possível abarcar todo o Primeiras estórias no espaço de um artigo, o conto "Famigerado" será analisado tanto para que a decifração fique mais bem estabelecida quanto para tentar demonstrar a validade do método de leitura que dela emerge.

\section{Decifração}

Para ir direto ao ponto: as Segundas estórias não foram publicadas porque as Primeiras estórias já as trazem dentro de si. Ou seja, as Segundas estórias já estavam publicadas também. Isso quer dizer que as estórias que compõem o volume são estruturadas de forma a conter duas estórias. Alguém poderia objetar que muitas narrativas podem ser lidas assim. Pense-se, por exemplo, naquelas em primeira pessoa em que um narrador pouco confiável conta sua história de forma a ocultar uma outra que, no entanto, também é contada - desde que o leitor seja suficientemente atento.

A particularidade de Primeiras estórias é a de que ele pode ser lido inteiramente assim, ou seja, a de que esse é um elemento de composição que está no centro dos contos ali reunidos. O que especifica acima de tudo o emprego dessa técnica neste livro é o embaralhamento de perspectivas, o jogo constante das aparências, e não só delas e daquilo que elas querem revelar, como também daquilo que elas, a sua revelia, revelam no final das contas.

Para entender o que se quer dizer aqui, é interessante considerar rapidamente dois contos em que essa duplicidade de estórias é particularmente perceptível, já que salta para a superfície do texto, além de apontar o efeito de embaralhamento referido.

O primeiro deles é "Nada e a nossa condição", conto no qual a crítica de certa forma já apontou aquilo que aqui chamamos de duplicidade das estórias. ${ }^{3}$ O projeto do narrador é o de exaltar um tio:

3. Ver, a esse respeito, o capítulo "Devaneios de um patriarca", em PACHECO, O lugar do mito, e SANTOS; CEZAR, "O patriarcalismo em 'Nada e a nossa condição' de João Guimarães Rosa", abordagens diferentes que apontam a mesma duplicidade. 
Na minha família, em minha terra, ninguém conheceu uma vez um homem, de mais excelência que presença, que podia ter sido o velho rei ou o príncipe mais moço, nas futuras estórias de fadas. Era fazendeiro e se chamava Man'Antônio. ${ }^{4}$

Ora, esse projeto, ao mesmo tempo que se concretiza, fracassa redondamente porque esse narrador, cego pela admiração ao velho parente e apegado aos valores que permitem essa admiração, acaba contando uma outra história paralela à que quer contar. O que ele conscientemente desenha é a figura do homem generoso e atilado que, após a morte da mulher, aumenta sua fortuna, cuida do futuro das filhas - "fingia estar vendendo as terras cabidamente; dinheiro pontual que mandava, pontual, às filhas e genros" ${ }^{5}$ - para em seguida fazer o mais generoso e incompreendido dos gestos, doar o que lhe era mais precioso - "entre seus muitos servos, pretos, brancos, mulatos, pardos leguelhés prequetés, enxadeiros e camaradas [...] então Tio Man'Antônio doou e distribuiu suas terras".

No entanto, a confiança desse narrador na superioridade não só de seu tio, mas de toda sua família em relação aos empregados, aqueles leguelhés prequetés, faz com que uma outra estória se revele. Ele registra a ausência de gratidão dos que receberam as terras e se revolta com ela:

Faziam de conta que eram donos, esses outros, se acostumavam. Não o compreendiam. Não o amavam, seguramente, já que sempre teriam de temer sua oculta pessoa e respeitar seu valimento, ele em paço acastelado, sempre majestade.

O leitor que acompanha o conto a esta altura se pergunta: como assim "faziam de conta que eram donos"? Pois as terras não lhes foram doadas? Não eram suas legitimamente? E ainda: de onde vem essa majestade, da grandeza do homem ou do fato de que ele doara quase todas as terras, reservando para si a casa senhorial, localizada no alto, de onde vigiava a todos?

Essas perguntas podem ser feitas porque o narrador, ao assumir uma dualidade rígida de certo-e-errado, acaba instaurando, ao condená-la, a

4. ROSA. Primeiras estórias, p. 80.

5. ROSA. Primeiras estórias, p. 86.

6. ROSA. Primeiras estórias, p. 86.

7. ROSA. Primeiras estórias, p. 87. 
perspectiva dos "beneficiários ingratos" da generosidade do velho parente, em tudo diferente da sua própria. Ao lado da figura da primeira estória, a do homem generoso que divide o que tem, avulta a figura dominadora da segunda estória, alguém que divide bens agora excedentes, já que sua fortuna se multiplicou e migrou para a cidade, onde vivem as filhas, sem abrir mão da posição simbólica de proprietário vetusto e senhor que submete todos os beneficiários a um controle constante. Ana Paula Pacheco procura sintetizar essa duplicidade quando diz que se trata de "narrador contradito por outras vozes que subsistem tensamente no discurso, a despeito de se calarem no final" ${ }^{8}$.

A situação é menos de contradição do que de convivência das duas lógicas numa experiência histórica particularmente complexa como é a da modernização, especialmente no conturbado caso brasileiro. Uma, privilegiada na primeira estória, é a senhorial, que o tio Man'Antônio procura conservar ao permanecer encastelado vigiando a todos, e que efetivamente está preservada na visão de seu sobrinho, o narrador. A outra, que emerge na segunda estória, a daqueles que "decerto, milenar e animalmente, o odiavam" e repelem aquela majestade, é a lógica moderna que instaura a igualdade entre os indivíduos.

O segundo conto, sobre o qual será preciso falar um pouco mais, é "A benfazeja". Nele, a própria constituição do narrador, que interpela uma comunidade inteira por conta da forma como todos ali julgam uma mulher, a Mula-Marmela, depende da convivência de duas estórias. A primeira é aquela que a comunidade criou; a segunda, a que o narrador afirma ser a verdadeira. Para a comunidade, aquela era uma mulher má que havia matado o marido e, suspeitava-se, o enteado. O narrador, por sua vez, desentranha desse enredo de assassinato um outro, no qual os próprios assassinatos, além do envenenamento que cegara o enteado anos antes de sua morte, não eram gestos de maldade. Eram antes sinais de renúncia - pois ela os amava - e de preocupação com o bem comum, já que os mortos eram malvados acabados.

O método narrativo das duas estórias cria uma dissonância enorme em "A benfazeja". O narrador faz uma série de perguntas, como esta: "E vocês ainda podem culpar essa mulher, a Marmela, julgá-la, achá-la vituperável? Deixem-na, se não a entendem, nem a ele [o enteado]. Cada qual com sua baixeza; cada um com sua altura" ${ }^{10}$. Com essa atitude, cria uma distância intransponível

8. PACHECO. Lugar do mito, p. 217-218.

9. ROSA. Primeiras estórias, p. 88.

10. ROSA. Primeiras estórias, p. 131. 
entre aquele que vem de fora, o próprio narrador, alguém capaz de entender a Mula-Marmela, e todos os outros, os do lugar, que nem sequer seu nome se deram ao trabalho de saber durante os longos anos em que ela ali viveu, contentando-se em condená-la e marginalizá-la.

Ora, julgamentos tão distintos fazem pensar em sistemas de valores distintos. Mas essa distinção é apenas aparência, uma vez que os valores que ele evoca para demonstrar a grandeza da Mula-Marmela são apenas parcialmente menos convencionais. Sim, ela era uma pobre a quem ninguém prestava atenção; ele, ao contrário, procurara vê-la como indivíduo, tendo mesmo falado com ela, a ponto de poder revelar a todos atos que ninguém poderia atribuir-lhe, como o de cegar o enteado. Por outro lado, o que ele usa para justificar a conduta da Marmela e estabelecer a generosidade e o autossacrifício como motor de tudo o que fez é algo que está absolutamente dentro da lógica daqueles que acusa:

Seu antigo crime [o assassinato do marido]? Mas sempre escutei que o assassinado por ela era um hediondo, o cão de homem, calamidade horribilíssima, perigo e castigo para os habitantes deste lugar. Do que ouvi, a vocês mesmos, entendo que, por aquilo, todos the estariam em grande dívida, se bem que de tanto não tomando tento, nem essa gratidão externassem.

Pensando em termos da figuração que todo o volume Primeiras estórias faz do processo de modernização brasileiro, não é difícil apontar um impasse: o narrador que acusa a comunidade de convencionalismo o faz dentro da lógica convencional. O que parecia ser a intervenção de um pensamento moderno, que quer descobrir nas ações de cada indivíduo, mais do que nas origens ou no posicionamento de classe, o valor de cada um, está baseado numa ordem antiga, em que a justiça é feita de forma cega, a velha lógica de que "bandido bom é bandido morto", não importa se isso está ou não previsto na lei - e não está.

Mas, como se disse, a técnica das duas estórias causa um embaralhamento de perspectivas mais profundo e um jogo de aparências muito mais intrincado do que um simples jogo de aparências.

Uma analogia com Bola de Sebo, de Maupassant, pode ajudar a esclarecer esse ponto fundamental. Lá, um narrador em terceira pessoa clássico

11. ROSA. Primeiras estórias, p. 126. 
apresenta um ato de generosidade da personagem-título. No entanto, esse ato não é compreendido como generoso pelos demais personagens, exceto, é claro, quando se beneficiarão dele e é preciso convencer a moça a aceitar levá-lo a cabo.

O enredo é bem conhecido. Um grupo de pessoas viaja numa "grande diligência de quatro cavalos" pela França, aproveitando um período de calmaria durante a guerra franco-alemã de 1870. Trata-se de grupo bastante representativo, já que dele fazem parte membros da grande burguesia, da nobreza, duas freiras e outras duas pessoas de condição muito diferente, um rapaz referido como "terror das pessoas respeitáveis" ${ }^{13}$, e a personagem-título descrita indiretamente da seguinte maneira: "Assim que ela foi reconhecida, cochichos correram entre as mulheres honestas, e as palavras 'prostituta' e 'vergonha pública' foram sussurradas tão alto que ela levantou a cabeça”. ${ }^{14}$ O grupo é retido numa estalagem de terceira categoria, impedido de seguir porque o comandante prussiano que ali dava as ordens deseja a jovem que os demais consideram decaída. Acontece que ela era uma nacionalista que já havia se indisposto com soldados prussianos e se recusa a atender o pedido do comandante. Irritados por estarem presos naquele fim de mundo, em pleno inverno, os companheiros de viagem de Bola de Sebo começam todo um movimento para convencer a moça a se entregar, e com isso encerrar o impasse, o que envolve até mesmo a condessa (que prepara o caminho, perguntando) e as freiras (que o completam, respondendo):

\footnotetext{
"Então, irmã, a senhora pensa que Deus aceita todos os caminhos e perdoa o ato quando o motivo é puro?"

"Quem poderá duvidar, minha senhora? Uma ação condenável em si torna-se meritória pelo pensamento que a inspira." ${ }^{15}$
}

Em suma: a pressão é enorme e a pobre moça acaba cedendo e se sujeitando a um sacrifício pessoal quase insuportável que libertaria todo o grupo. No dia seguinte, nenhum reconhecimento lhe vem desse sacrifício. Ao contrário, a ideia antes expressa de que para ela tanto faria, já que Bola de Sebo se deitava com qualquer homem, acaba se impondo, e o tratamento que recebe é ainda

12. MAUPASSANT. Boule de Suif, p. 5. Traduzi para citar.

13. MAUPASSANT. Boule de Suif, p. 9. Traduzi para citar.

14. MAUPASSANT. Boule de Suif, p. 10. Traduzi para citar.

15. MAUPASSANT. Boule de Suif, p. 30. Traduzi para citar. 
mais frio do que antes, como se o que fizera para salvá-los provasse somente quão decaída ela era. E, nesta parte final da viagem, nem um pouco de comida lhe dão, justo a ela que antes, na primeira parte da jornada, alimentara a todos.

Nesta narrativa, o jogo de aparências é diretamente percebido por meio de uma espécie de inversão de valores. A criatura mais nobre de todas - nobreza que o autossacrifício demonstra - por estar fora do radar da moral burguesa é tida como vil por outras criaturas, essas claramente vis exatamente porque colocaram suas conveniências tanto acima dos valores coletivos (a nação) quanto das convicções de uma outra pessoa. São dois sistemas de valores que se opõem, o da moral burguesa tradicional cheia de ideias pré-concebidas, e um outro, definitivamente mais moderno, que reconhece o valor dos indivíduos pelos atos que praticam, independentemente de suas origens sociais. Seria possível dizer que em Bola de Sebo também temos como localizar duas histórias? Não, porque os dois sistemas de valores como que se anulam, ao se complementarem. Ao sair da leitura do texto, ninguém tem dúvida de que a única história ali narrada é a da grandeza da protagonista e da hipocrisia dos demais. A diferença de perspectivas entre o que se considera vil de um lado e de outro se anula, convertendo-se numa visão só em que fica claramente discernível quem é vil e quem não é.

Em "A benfazeja” tudo se dá de forma muito diferente. Trazidas as duas estórias para a superfície na voz desse narrador acusatório, ficam preservadas as duas perspectivas distintas. Por outro lado, quando o narrador transige com os valores a que se opõe, justificando a validade de sua perspectiva com a lógica violenta que pertence à perspectiva da comunidade a que se dirige e acusa, tudo fica mais embaralhado e, portanto, mais complicado. A isso se soma a gravidade dos atos da Mula-Marmela, que vão muito além de atentados a uma convencional moralidade burguesa: ela mata e ela cega.

Em Bola de Sebo somos levados a perguntar coisas como "em que os companheiros de viagem são melhores do que Bola de Sebo?", ou mesmo "em que o comandante prussiano é pior do que os companheiros de viagem de Bola de Sebo?" Mas ninguém é levado a uma pergunta do tipo "em que Bola de Sebo é pior que seus companheiros de viagem ou que o comandante prussiano?" Não. Bola de Sebo é melhor que eles. A personagem representa a referência ética inquestionável (e pouco visível para quem julgue prostituição e dignidade incompatíveis) que estrutura tanto a narrativa quanto o comentário que ela quer fazer sobre aquela sociedade. 
Em "A benfazeja", ao contrário, somos levados a perguntar também algo como "em que mesmo a Marmela é melhor do que os assassinos que ela matou?" Ou ainda: "em que o narrador é melhor que os habitantes daquele lugar"? Mas nos perguntamos apenas para ficar sem respostas conclusivas. Todas as formas de raciocínio baseadas na dualidade do certo e do errado caem por terra. Afinal, quando o narrador assume o ponto de vista violento que vê grandeza nos crimes de Marmela porque eles livraram a todos de dois malfeitores, é verdade que podemos reaproximá-lo dos valores que combate. Mas também é verdade que isso pode não passar de estratégia retórica para chamar a atenção tanto sobre o julgamento estereotipado que fazem da Marmela quanto sobre a perspectiva viciada que dá lugar a esse julgamento. Ou seja, é possível que o projeto do narrador, afinal de contas, não seja o de reabilitar aquela mulher, mas sim o de mostrar que é possível reabilitá-la, de que é preciso compreender cada indivíduo, seja quem for, em seus próprios termos. E que isso é possível desde que se perceba que o que aquela comunidade usa para justificar a condenação moral da Marmela (não perdoá-la por seus crimes) é apenas uma aparência de justiça - e de justiça moderna, que recusa a lógica do olho-por-olho. Afinal, ninguém toma providências legais contra a assassina: apenas a marginalizam enquanto aceitam os benefícios de seu crime.

É assim que, em "A benfazeja”, a duplicidade das estórias de uma mulher que está na superfície do texto remete para a duplicidade do próprio narrador e, se quisermos, para as ambiguidades do processo de modernização brasileiro.

\section{3. "Famigerado"}

Em contos como "Nada e a nossa condição" e "A benfazeja", as "duas estórias" se oferecem de forma mais ou menos direta aos leitores, pela própria constituição peculiar da voz narrativa. Mas nem sempre é assim. Em muitos dos contos das Primeiras estórias as segundas ficam latentes nas primeiras e exigem mais do leitor que as queira desentranhar. Este é bem o caso de "Famigerado".

Neste texto temos um narrador letrado que nos diz, anunciando o caráter inesperado e único do que vai contar: "Foi de incerta feita - o evento". ${ }^{16}$

16. ROSA. Primeiras estórias, p. 9. 
E esse evento único foi o contato entre duas pontas distantes da sociedade: o médico da cidade pequena e o velho jagunço valentão. A primeira estória é a "tese para alto rir" ${ }^{17}$, o caso jocoso de como o doutor, com suas armas de homem letrado, deu um nó no jagunço. A primeira estória é a da vitória da letra sobre as armas, do esclarecimento sobre o obscurantismo, do moderno sobre o arcaico.

Dá-se que o jagunço, Damázio, morador de um lugar remoto (distante seis léguas ou quarenta quilômetros da cidade em que vive o doutor), foi chamado de famigerado por um "moço do Governo" ${ }^{18}$ que se estabelecera havia pouco tempo naquelas bandas. Por não saber se se tratava ou não de ofensa, decide recorrer a quem soubesse para pôr aquilo em pratos limpos. O doutor, é claro, assusta-se com a visita daquele homem, mas afinal acaba percebendo que tudo se passaria dentro dos limites daquilo que lhe era confortável. Tirando proveito da ambiguidade da palavra, livra-se da situação ao garantir que famigerado não era ofensa, chegando mesmo a dizer que "eu, como o sr. me vê, com vantagens, hum, o que eu queria uma hora destas era ser famigerado-bem famigerado, o mais que pudesse!" ${ }^{19}$ Com isso, engana o jagunço e salva a pele do moço do Governo.

José Miguel Wisnik, em análise conhecida, que procura evidenciar o jogo entre moderno e arcaico que Primeiras estórias mobiliza, sintetiza este conto afirmando que "podemos considerar o narrador de 'Famigerado' um Pedro Malasartes erudito, ou, a sua estória, algo assim como o improvável duelo do jagunço com um jabuti doutoral”. ${ }^{20}$ Ana Paula Pacheco não se distancia dessa leitura, mas tira dela consequência específica que quer apontar uma espécie de contradição da obra de Guimarães Rosa: "A 'lábia civilizada' do narrador (que lembra a habilidade do escritor que dignifica para a cidade o sertão, pelo famoso estilo, pela maneira de representar o mundo sertanejo) neste conto parece justamente diminuir este outro (jagunço) que se procura representar". ${ }^{21}$

Essas análises contemplam apenas a "primeira estória" de "Famigerado". E se na "segunda estória" descobrirmos que a vitória acachapante do doutor sobre o jagunço de fato não é a única conclusão a que "o evento" nos permite chegar? E se pudermos nos perguntar quem será o verdadeiro Pedro Malasartes neste caso?

17. ROSA. Primeiras estórias, p. 13.

18. ROSA. Primeiras estórias, p. 11.

19. ROSA. Primeiras estórias, p. 12.

20. WISNIK. O famigerado, p. 186.

21. PACHECO. O lugar do mito, p. 78. 
O doutor conta acontecimentos vividos sob o domínio do medo que Damázio lhe causa. Ainda antes de saber de quem se tratava, imagina: "só podia ser um brabo sertanejo, jagunço até na escuma do bofe". ${ }^{22}$ E pensa: "O medo me miava". ${ }^{23}$ Depois, quando o homem se identifica, ele ainda mais uma vez se assusta: "Sobressalto. Damázio, quem dele não ouvira? O feroz de estórias de léguas, com dezenas de carregadas mortes, homem perigosíssimo". ${ }^{24} \mathrm{Nem}$ a evocação da voz geral, que o dizia serenado, é capaz de acalmá-lo: "Fie-se, porém, quem, em tais tréguas de pantera?"

Embora conduza a narração, feita a posteriori, tudo parece indicar que quem conduz as ações narradas seja mesmo o jagunço. Afinal, como o próprio doutor reconhece, "O medo é a extrema ignorância em momento muito agudo". ${ }^{26}$ E narrador parece ter uma consciência difusa de suas incertezas, já que o tempo todo, ao caracterizar as ações de Damázio, ele o faz por meio de perguntas ("por esperteza?" ${ }^{27}$ ), de suposições ("Se é que se riu", "Se sério, se era" ${ }^{28}$ ) ou do uso do condicional ("seriam seus prisioneiros" $"$ ).

Não só isso. O ritmo dos acontecimentos é determinado por Damázio. Diante da situação inusitada, tudo o que o médico pode fazer é supor o que aquele homem está fazendo ali, e Damázio o mantém o tempo todo preso a suas próprias suposições, sem qualquer esclarecimento. Primeiro, mostra respeito, declinando o convite para entrar, "conquanto os costumes". Em seguida, o doutor dirige-lhe uma pergunta e ele começa esclarecendo o que não vinha fazer ali: consultar-se. Apenas anuncia: "Eu vim preguntar a vosmecê uma opinião sua explicada..." Mas a pergunta, aquilo que o levou até ali, é retardada o máximo possível. Desce do cavalo, o que dá oportunidade ao médico de observar que ele estava armado, "e com armas alimpadas", seu cavalo era cara, fruto de um trabalho primoroso, que ele era do norte, que

22. ROSA. Primeiras estórias, p. 9.

23. ROSA. Primeiras estórias, p. 9.

24. ROSA. Primeiras estórias, p. 10.

25. ROSA. Primeiras estórias, p. 10.

26. ROSA. Primeiras estórias, p. 9.

27. ROSA. Primeiras estórias, p. 10

28. ROSA. Primeiras estórias, p. 10

29. ROSA. Primeiras estórias, p. 9.

30. ROSA. Primeiras estórias, p. 10.

31. ROSA. Primeiras estórias, p. 10

32. ROSA. Primeiras estórias, p. 10 
era forte, "todo em tronco de árvore". ${ }^{33}$ Só depois é que o homem se apresenta como Damázio, dos Siqueiras. O que o exame do narrador adivinhara, em sua primeira suposição, ele o confirma, já que se tratava de valentão conhecido.

Tendo-se identificado, pode enfim passar à pergunta. Mas não o faz. Primeiro começa a contar do moço do Governo, "Saiba que estou com ele em revelia..." ${ }^{34}$ diz, e se interrompe. Muda de assunto: "O que de frouxo falava: de outras diversas pessoas e coisas, da Serra, do São Ão, travados assuntos, insequentes, como dificultação"." Mas não leva a história adiante, muda de assunto sem concluí-la. Enfim, enrola muito, foge do assunto principal, tudo para lançar a pergunta de maneira inesperada, como quem dá um tiro, assim descrito:

E, pá:

- "Vosmecê agora me faça a boa obra de querer me ensinar o que é mesmo que é: fasmigerado... faz-me gerado... falmisgeraldo... famílias-gerado...? Disse, de golpe, trazia entre dentes aquela frase. ${ }^{36}$

Essa introdução abrupta pode fazer supor que agora ele tem pressa de obter um esclarecimento. Mas não. Ele continua falando, não abre espaço para que a resposta venha: explica que veio de longe, que por lá não há quem possa resolver aquele problema, falta o dicionário e só o padre talvez pudesse responder, mas não se dá com padres, que "eles logo engambelam". ${ }^{37}$ O doutor percebe esse retardamento: "Detinha minha resposta, não queria que eu a desse de imediato". ${ }^{38}$ Não esboça, no entanto, nenhuma outra reação senão a de se declarar esperto o suficiente para notar a atitude do jagunço.

O que ele não percebe é que está sendo manipulado por Damázio. O jagunço lhe dá tempo para fazer aquilo que ele vinha fazendo, suposições. E, como é natural numa situação como essa, diante da possibilidade de eclosão da violência, e desconhecendo as intenções do interlocutor, o medo conduz a uma suposição terrível:

33. ROSA. Primeiras estórias, p. 10.

34. ROSA. Primeiras estórias, p. 11.

35. ROSA. Primeiras estórias, p. 11.

36. ROSA. Primeiras estórias, p. 11.

37. ROSA. Primeiras estórias, p. 12.

38. ROSA. Primeiras estórias, p. 11. 
E já aí um outro susto vertiginoso suspendia-me: alguém podia ter feito intriga, invencionice de atribuir-me a palavra de ofensa àquele homem; que muito, pois, que aqui ele se famanasse, vindo para exigir-me, rosto a rosto, o fatal, a vexatória satisfação?

Como se vê, o moço do Governo, que apenas no parágrafo final se estabelecerá inequivocamente como aquele que poderia ter ofendido Damázio, misturara-se a todas as outras coisas insequentes ditas, desaparecendo do horizonte de suposições do médico, que vê a si mesmo como potencial vítima do jagunço.

A suspensão provocada por Damázio se encerra com a interpelação direta para que o doutor responda. Estamos, a esta altura, já na parte final do conto. É somente na linha 108, de um total de 150 na edição aqui utilizada, que finalmente o médico pode começar a responder, ainda sem ter se dissipado a suspeita de que alguém o intrigara, de que daquela resposta poderia depender sua vida. Seu estado de nervos é tal que agora ele é quem retarda a resposta, como quem pisa em ovos, pensando no que poderia dizer. O medo fizera seu efeito. Repete a palavra famigerado, olha "como por socorro" ${ }^{40}$ para os três calados cavaleiros, para apenas então recobrar o sangue frio capaz de o tirar da enrascada: "Só tinha de desentalar-me". "11 É somente a partir daí que o Pedro Malasartes erudito passa a atuar, operando sobre o duplo sentido da palavra, elidindo o que era ofensivo (e evidente) ao mesmo tempo em que ressalta seu sentido elogioso (e pouco corrente), com o objetivo de acalmar o jagunço e afastar a violência que lhe parece iminente. De quem sabe salvar a própria pele.

Esse movimento geral do enredo mostra que Damázio impôs seu jogo ao doutor. Ele talvez seja o primeiro Pedro Malasartes, aquele que conduz o encontro ao final pretendido. Em duas palavras: Damázio talvez deseje ser enganado e talvez provoque esse engano. A pergunta a se fazer a esta altura é a seguinte: e por que ele desejaria uma tal coisa?

E a resposta nem é tão difícil assim. Damázio vive, neste momento, uma situação nova e bastante delicada. ${ }^{42}$ A própria chegada de "um moço

39. ROSA. Primeiras estórias, p. 11.

40. ROSA. Primeiras estórias, p. 12

41. ROSA. Primeiras estórias, p. 12.

42. Os textos aqui referidos de José Miguel Wisnik e Ana Paula Pacheco desenvolvem longamente esse aspecto do conto. 
do Governo" naqueles ermos indica que uma lógica moderna, que implica a aplicação impessoal da justiça, está sendo instalada ali. Por outro lado, sua própria identificação está atrelada à lógica do mandonismo, que pode estar com seus dias contados mas ainda vige. Afinal, ele se apresenta como "Damázio, dos Siqueiras”, não como Damázio Siqueira, ou seja, como o indivíduo que se define por sua ligação com uma família não por laços de sangue, mas por laços de mando: ele é o jagunço dos Siqueiras.

Ou, sendo mais preciso, dois sistemas ali convivem, obrigando pessoas como Damázio a prestar contas a Deus e ao Diabo juntamente. O jagunço vive sobre o fio da navalha. A ética por assim dizer arcaica ainda está de pé e ela o impede de simplesmente deixar uma ofensa passar em branco, imerso que está na mesma ética que comanda o famoso embate final de "A hora e a vez de Augusto Matraga”, entre Matraga e Joãozinho Bem-Bem, já que este não pode atender ao pedido que aquele lhe faz para poupar a vida de um determinado homem simplesmente porque aquilo ia contra as regras. Mas a ética moderna, que repele o olho-por-olho e exige a intermediação da justiça formalmente constituída entre quem ofende e quem é ofendido, também é vigente e o impede de agredir o tal moço que, além de tudo, é representante desse intermediador universal, o governo.

Quando se pensa nas motivações de Damázio para procurar o doutor, é preciso perguntar: por que um jagunço teria a necessidade de confirmar uma ofensa antes de matar ou ferir alguém? Ora, a simples suspeita já é bastante, ou mesmo o obriga, na lógica jagunça, à rápida prestação de contas. Mesmo José Miguel Wisnik, que não cogita esta segunda estória, diz: "nada impediria a Damázio, dado seu curriculum, de matar sem perguntar". Aliás, caberia até uma pergunta anterior a essa: será que Damázio tem mesmo dúvida de que a palavra era ofensiva? A língua na prática tem muitas dimensões que os dicionários não podem capturar. Aquela qualificação lhe foi atribuída num contexto determinado e foi compreendida de alguma maneira lá no São Ão, por aqueles que convivem com Damázio e em relação a quem lhe interessa manter seu estatuto de forte. Era difícil ao jagunço provar que haveria "Vilta nenhuma, nenhum doesto" palavra famigerado, para usar a fórmula cifrada que o nosso narrador evocaria para, num primeiro momento, ainda indeciso, indicar que nada havia de ofensivo.

43. WISNIK. O famigerado, p. 181.

44. ROSA. Primeiras estórias, p. 12 
A obrigação de matar o moço e colocar-se em posição complicada, sobretudo para um jagunço em fim de carreira, praticamente "de range rede" mas ainda "dos Siqueiras", não herdeiro como Riobaldo, impunha-se. Enfim, a motivação de Damázio ao procurar o doutor não era a de pôr a ofensa em pratos limpos para poder matar o moço do governo de consciência limpa (o que soa até estranho). Era, isso sim, a de encontrar justificativa para não matar o moço do governo e ainda assim não perder o estatuto de valentão que lhe garantia o sustento e a posição social.

Era preciso procurar uma voz autorizada - mas distante - que garantisse não ter havido "vilta nenhuma". Além disso, era preciso que essa voz de longe fosse ouvida por alguém de perto. Lembre-se que, logo à chegada, Damázio e os outros três cavaleiros se colocam em posição que os protege do olhar da rua. Afinal, se o que ele vem buscar ali é um motivo para não pôr em andamento as ações violentas, não interessa que aquela comitiva chame a atenção ou pareça assustadora:

Dado que a frente da minha casa reentrava, metros, da linha da rua, e dos dois lados avançava a cerca, formava-se ali um encantoável, espécie de resguardo. Valendo-se do que, o homem obrigara os outros ao ponto onde seriam menos vistos, enquanto barrava-lhes qualquer fuga; sem contar que, unidos assim, os cavalos se apertando, não dispunham de rápida mobilidade. ${ }^{45}$

Damázio está em situação tão delicada que se obriga a colocar-se em posição incômoda para um jagunço. Afinal, ele próprio estaria em dificuldade se quisesse fugir, já que seu cavalo também estava apertado com os outros três. E note-se como o doutor lê no posicionamento dos homens somente a marca da força do homem, que impedia a fuga dos outros três, sem se dar conta de que, daquela maneira, ele dificultava a sua própria fuga - o que poderia ser sinal de que ele não tinha intenção de cometer qualquer crime nessa sua visita.

Qual seria então a função desses três homens, "seus prisioneiros, não seus sequazes" " aquele assassinato que não era de seu interesse praticar? Essa função se confirma no fecho da narrativa, quando Damázio os dispensa assim que o doutor dá

45. ROSA. Primeiras estórias, p. 9.

46. ROSA. Primeiras estórias, p. 9. 
demonstração inequívoca de que famigerado não só não era ofensivo como se tratava de elogio: " - Vocês podem ir, compadres. Vocês escutaram bem a boa descrição...' - e eles prestes se partiram".

A segunda estória de "Famigerado", portanto, é um espelho da primeira. Numa, quem faz as vezes de Pedro Malasartes, como diz José Miguel Wisnik, é o narrador, o doutor que engambela o jagunço ignorante. E esta é a primeira estória porque é aquela em que a voz narrativa crê e a que ele quer contar. Na outra, quem faz o papel do malandro esperto é Damázio, que induz o doutor a lhe dizer o que ele quer ouvir - e possa ser ouvido por outros. Esta é a segunda estória porque se escreve à revelia do narrador, mais sutilmente do que acontece em "Nada e a nossa condição", porém de forma análoga.

Chegando neste ponto, há ainda uma precaução a mais a tomar: não cair na armadilha de pensar que o jagunço é quem sai vitorioso, de que só a segunda estória existe. Sim, é verdade, depois de ter a confirmação de que famigerado não era vitupério, ele fica "exultante" ${ }^{48}$, o que indica que se considera vitorioso - afinal, quem ficaria exultante por não fazer algo a que estava habituado e que de fato cogitasse fazer? No entanto, ele acrescenta: "Sei lá, às vezes o melhor mesmo, pra esse moço do Governo, era ir-se embora, sei não..." ${ }^{49}$ Sim, a forma de enunciar isso, dizendo que ir embora seria melhor para o moço e não para ele, reafirma seu caráter ameaçador e sua vitória. Mas também há algo de melancólico nessa repetição do "sei lá" inicial no "sei não" final, que indica a consciência de que isso não acontecerá. Diferentemente de Naziazeno, protagonista de Os ratos, de Dyonélio Machado, que prefere considerar tudo resolvido quando obtém, endividando-se, o dinheiro para pagar aquele mês ao leiteiro, o lamento de Damázio revela a consciência de que o moço não vai embora - que bom se fosse. Afinal, depois que chega o governo, sempre haverá um moço a representá-lo. Se a posição do doutor moderno é instável diante da violência que a qualquer momento Damázio pode perpetrar, a instabilidade do jagunço não é menor, ameaçado que está por qualquer moço do governo que, exatamente por ser do governo, não pode ser dissolvido "com um pingo no i".

E, é bom insistir, consideradas as duas estórias, ninguém é melhor que ninguém. Em ambas, a mesma ação de fundo, algo desprezível, está presente:

47. ROSA. Primeiras estórias, p. 12-13.

48. ROSA. Primeiras estórias, p. 12.

49. ROSA. Primeiras estórias, p. 13

50. ROSA. Primeiras estórias, p. 9. 
a de fazer do outro mero instrumento, a serviço de suas conveniências ou como tese para alto rir. Sempre a mesma esperteza que gira no vazio, mantendo tudo exatamente como estava.

Compreendido desta maneira, em suas duas estórias, "Famigerado" não se afigura mais como uma simples diminuição do jagunço. Sim, a diminuição está lá, mas não como efeito total ou único da leitura. Restringe-se ao ponto de vista do narrador, à avaliação que faz sobre si mesmo e sobre aquele outro inculto - e a uma certa cumplicidade que ele estabelece com o letrado seu irmão, justamente o leitor, que, partilhando do julgamento de sua própria superioridade sobre o jagunço, pode rir com ele daquele que não é mais assustador porque não passa de um simplório, com isso mostrando-se, ele próprio, cego à inteligência desse outro.

O que o método narrativo das duas estórias permite aos contos de Primeiras estórias é uma figuração complexa que coloca em relação diferentes sistemas de valores sem elidir nenhum deles, sem alçar um à condição de norma e o outro à de desvio. Ao contrário, eles convivem e colidem, impedindo o leitor de tirar conclusões apressadas. Os dois sistemas praticam o jogo do engano, sem qualquer motivo "nobre" - a não ser o instinto de autopreservação - que justifique o comportamento canalha. Os dois lados do Pedro Malasarte - os dois lados da malandragem - preservam-se inteiros. O simpático, que desafia a ordem por atuar em suas frinchas e assim revelar a falta de integridade dessa ordem; e o outro, antipático, que exatamente por atuar nas frinchas da ordem jamais se volta contra ela - ao contrário, convive muito bem com ela, alimentase dela e, dessa forma, apenas a confirma.

Lido desta forma, Primeiras estórias se revela uma representação do processo de modernização brasileiro em sua integridade, uma convivência de arcaico e de moderno que ensaia uma síntese específica, brasileira, diferente da vivida em outras partes. Em nenhum lugar os valores modernos simplesmente substituem os valores arcaicos, antes convivem com eles e mesmo sobre eles se apoiam em contradição constante. No Brasil, essa contradição terá feição específica e profunda, que este livro figura com grande complexidade.

A mesma complexidade se dá na representação do outro, do universo do iletramento. É possível dizer que, com diferentes recursos e outra visão, Guimarães Rosa atinge em Primeiras estórias um feito comparável ao de Graciliano Ramos em Vidas secas: construir a figuração do mundo do iletrado pelo mundo letrado de forma que ambos permaneçam íntegros, em sua grandeza e em suas limitações e mesquinhezas. 


\title{
Second stories: an interpretation of "Famigerado"
}

\begin{abstract}
Based on the hipothesis that the stories from Guimarães Rosas' Primeiras estórias [First Stories] bring the never published "second stories" with them, this paper presents an interpretation method for the book as a whole and exemplifies this method by analysing one of them, "Famigerado".
\end{abstract}

Keywords: Guimarães Rosa, Brazilian fiction, Modernization.

$$
\text { Referências }
$$

\footnotetext{
MAUPASSANT, Guy de. Boule de Suif. Paris: ILV, s.d. E-book disponível em: http://www. inlibroveritas.net/telecharger/pdf_domaine_public/oeuvre2329.html. Último acesso em: 03 mar. 2014.
}

PACHECO, Ana Paula. Olugar do mito: Narrativa e processo social nas Primeiras estórias de Guimarães Rosa. São Paulo: Nankin, 2006.

PASTA JÚNIOR, José Antonio. O romance de Rosa: temas do Grande sertão e do Brasil. Novos Estudos Cebrap, São Paulo, n. 5, p. 61-70, nov. 1999.

RÓNAI, Paulo. Especulações sobre Tutaméia. In: Pois é: ensaios. Rio de Janeiro: Nova Fronteira, 1990. p. 13-21.

ROSA, Guimarães. Primeiras estórias. 6 ed. Rio de Janeiro: José Olympio, 1972.

SANTOS, Volnei Edson; CEZAR, Adelaide Caramuru. Patriarcalismo em "Nada e a nossa condição" de João Guimarães Rosa. In: SANTOS, Volnei Edson (Org.). Sopros do silêncio. Londrina: Eduel, 2008. p. 11-31.

WISNIK, José Miguel. O famigerado. Scripta, Belo Horizonte, v. 5, n. 10, p. 177-198, $1^{\circ}$ sem. 2002. 